\title{
The fruit of peach palm (Bactris gasipaes) and its technological potential: an overview
}

\author{
Rebeca Desireé Souza da COSTA ${ }^{1}$, Antônio Manoel da Cruz RODRIGUES ${ }^{1}$, Luiza Helena Meller da SILVA ${ }^{1 *}$ (D)
}

\begin{abstract}
The Amazon hosts numerous fruit species, which are consumed by the local population and distributed by the local economy in the commerce markets, but most of them are unknown to the general population. Therefore, for a better understanding of the Amazon biome, the main objective of this review was to describe the physicochemical, nutritional and biological characteristics of the peach palm, highlighting its antioxidant potential. The peach palm tree is considered a polyvalent palm native to tropical Latin America, predominantly cultivated by small farmers in agroforestry systems, its fruits present high potential for functional food production because of the presence of bioactive compounds in its composition, and high nutritive value with considerable amounts of carbohydrates and lipids, as well as it provides an important source of vitamin A. Thus, an approach has been taken on the main topics for further studies that may benefit the industry and improve the local economy where these fruits are found. In view of this, the dissemination of works already performed with this fruit, strategically relevant, can stimulate new lines of research to consolidate this field for food, pharmaceutical and cosmetic industries.
\end{abstract}

Keywords: Bactris gasipaes; carotenoids; fatty acids; nutritional composition; palm peach.

Practical Application: The review on the properties of the peach palm fruit gathers important information to expand knowledge and future valuation of the fruit, including all genotypes (microcarp, mesocarp and macrocarp).

\section{Introduction}

The peach palm tree (Bactris gasipaes) is a tropical plant, native from Americas that presents wide genetic diversity in its wild and domesticated population (Carvalho et al., 2013a). According to studies, there are approximately 73 species spread in South Mexico, the Caribbean, Brazil and Paraguay. The cultivated peach palm is widely distributed from Honduras to the Central region of Bolivia and Eastern Pará (Brazil) (Bezerra \& Silva, 2016; Graefe et al., 2013).

The peach palm tree can be cultivated with different purposes: for palm heart and fruit (popularly known as peach palm) (Bezerra \& Silva, 2016; Matos et al., 2019). In the Brazilian Amazon, the peach palm tree is almost exclusively cultivated for fruit purpose, which is consumed after its cooking in water and salt (Carvalho et al., 2013a; Chisté \& Fernandes, 2016).

The peach palm presents high nutritional value, rich in fat, fiber, starch and total carotenoids, among them the $\beta$-carotene that attributes to its pulp an intense yellowish color, besides its significant functional appeal (Table 1).

The presence of bioactive compounds in peach palm makes its consumption attractive due to the association with lower incidence of certain types of cancer and cardiovascular diseases. The antioxidant compounds act in the protection of molecules as lipids, DNA and proteins, against the oxidative attack (PérezMateos et al., 2005).

The high content of carotenoids present in the peach palm fruits are mentioned as the main responsible for the antioxidant action (Espinosa-Pardo et al., 2014; Jatunov et al., 2010), contributing to the ingestion of antioxidant compounds in the human diet (Carvalho et al., 2013b). As the carotenoids present a molecular structure of conjugated double bonds, they become powerful agents with antioxidant action (Jatunov et al., 2010) contributing to the strengthening of the immune system and reducing risks of diseases (Carvalho et al., 2013b; Serrano et al., 2011).

In addition to direct consumption, the fruit can be used as raw material to produce many products, especially peach palm flour, oils and fermented drink, for example. The peach palm in the form of flour is an alternative to avoid the market saturation of fresh fruits and to diversify its demand. High-starch mesocarp species are the most appropriate because when starch is heated, it tends to generate technological properties of interest for certain types of products, such as breads, cakes, soups, creams, sauces and porridge (Bezerra \& Silva, 2016).

The objective of this work is to present an overview of the published literature related to pupunha, from the physical and genetic characteristics of the fruits to their commercial use, with an emphasis on physical-chemical, nutritional, biological and technological characterization as well as in the elaboration and commercialization of new products.

\section{Peach palm (Bactris gasipaes)}

In Brazil, there are different types of soil and climate resulting in great diversity of fruit species distributed around the six biomes (Amazon Forest, Caatinga, Cerrado, Atlantic Forest, Pantanal and Pampa) (Neri-Numa et al., 2018). The Amazon 
Table 1. Physical characterization, nutritional composition, and amino acids of the protein in the mesocarp of peach palm (Bactris gasipaes) fruits (in natura) with comparisons to $\mathrm{FAO} / \mathrm{WHO}$ recommendations and the literature.

\begin{tabular}{|c|c|c|c|c|c|c|c|c|c|}
\hline \multicolumn{10}{|c|}{ Biometric analysis of peach palm fruit } \\
\hline Genotype & & Seed & Peel color & \multicolumn{2}{|c|}{ Weight $(\mathrm{g})$} & \multicolumn{3}{|c|}{ Diameter $(\mathrm{cm})$} & Reference \\
\hline Macrocarpa & & Presence & Red-green & \multicolumn{2}{|c|}{$45.45 \pm 8.18$} & $3.97 \pm 0.30$ & \multicolumn{2}{|c|}{$4.93 \pm 0.43$} & (Pires et al., 2019) \\
\hline Microcarpa & & Absence & Green & \multicolumn{2}{|c|}{$21.20 \pm 3.56$} & $1.99 \pm 0.15$ & \multicolumn{2}{|c|}{$2.95 \pm 0.20$} & (Costa et al., 2019) \\
\hline Mesocarpa & & Presence & Yellow-green & \multicolumn{2}{|c|}{$30.05 \pm 2.15$} & $3.14 \pm 0.22$ & \multicolumn{2}{|c|}{$3.03 \pm 0.13$} & \\
\hline Macrocarpa & & Presence & Red-green & \multicolumn{2}{|c|}{$52.30 \pm 1.98$} & $4.68 \pm 0.10$ & \multicolumn{2}{|c|}{$5.63 \pm 0.32$} & \\
\hline Macrocarpa & & Presence & Yellow-red & \multicolumn{2}{|c|}{58} & \multicolumn{3}{|c|}{-} & (Clement et al., 1998) \\
\hline & & & Nutri & tional compos & sition macroc & carpa $(\mathrm{g} 100$ & & & \\
\hline Moisture & & Lipids & Proteins & & Ashes & Total fiber & & Starch & (Arkcoll \& Aguiar, 1984) \\
\hline 44.3 & & 23.0 & 6.9 & & 1.3 & 9.3 & & 59.5 & (Andrade et al., 2003) \\
\hline $46 \pm 0.42$ & & $.93 \pm 0.43$ & $1.30 \pm 0.09$ & 0.72 & $2 \pm 0.31$ & $0.76 \pm 0.12$ & 44.3 & $32 \pm 0.32$ & (Ferreira \& Pena, 2003) \\
\hline 68.5 & & 1.9 & 2.4 & & 0.5 & 1.6 & & - & (Yuyama et al., 2003) \\
\hline $47.0 \pm 3.5$ & & $7.7 \pm 3.2$ & $2.3 \pm 0.4$ & & $5 \pm 0.1$ & $6.6 \pm 1.5$ & & - & (Carvalho et al., 2013b) \\
\hline $43.90-65.39$ & & $.25-40.83$ & $4.20-6.47$ & 1.08 & $8-2.54$ & $0.87-3.40$ & & - & (Costa et al., 2019) \\
\hline $50.69-57.76$ & & $2.24-5.50$ & $1.39-2.54$ & 1.15 & $5-1.37$ & - & & - & \\
\hline $47.98-63.96$ & & $2.62-6.88$ & $2.00-3.90$ & 0.80 & $0-2.74$ & - & & - & (Pires et al., 2019) \\
\hline & & & Essentia & 1 minerals cor & mposition ma & acrocarpa $(10$ & $\left.00 \mathrm{~g}^{-1}\right)$ & & \\
\hline $\mathrm{Ca}(\mathrm{mg})$ & $\mathrm{K}(\mathrm{mg})$ & $\mathrm{Na}(\mathrm{mg})$ & $\mathrm{Cl}(\mu$ & $\mathrm{Mn}(\mu \mathrm{g}$ & $\mathrm{Zn}(\mu \mathrm{g})$ & $\operatorname{Se}(\mu \mathrm{g})$ & Iron $(\mu \mathrm{g})$ & $\mathrm{Cr}(\mu \mathrm{g})$ & \\
\hline $21.8 \pm 2.4 \quad 206$ & $06.4 \pm 3.3 \quad 12$ & $12.6 \pm 2.0 \quad 17.6$ & $\pm 1.0 \quad 30.7 \pm$ & $3.7 \quad 82.6 \pm 8$. & $8.7278 .3 \pm 30$ & $.411 .4 \pm 0.7$ & $739.3 \pm 130.5$ & $513.9 \pm 0.9$ & (Yuyama et al., 2003) \\
\hline 800 & 2000 & 500 & $2.0-5.0$ & $(\mathrm{mg})$ & 70 & 10 & $50-200$ & $8.2 \pm 0.4$ & $\mathrm{RDA}$ \\
\hline $2 \%$ & $12 \%$ & $1 \%$ & $2 \%$ & $5 \%$ & $2 \%$ & $9 \%$ & $6 \%$ & $9 \%$ & Mean contribution \\
\hline & & & Non-essen & tial minerals & composition & macrocarpa & $\left(100 g^{-1}\right)$ & & \\
\hline $\mathrm{Au}(\mathrm{ng})$ & $\mathrm{Ba}(\mu \mathrm{g})$ & $\mathrm{Br}(\mu \mathrm{g})$ & $\mathrm{Ce}(\mu \mathrm{g})$ & Se (ng) & $\mathrm{Pa}(\mu \mathrm{g})$ & $\mathrm{Sb}$ (ng) & $\mathrm{La}(\mathrm{ng})$ & $\mathrm{Rb}(\mu \mathrm{g})$ & \\
\hline $57.8 \pm 2.2$ & $103.9 \pm 2.6$ & $143.5 \pm 8.7$ & $2.1 \pm 0.4$ & $10.4 \pm 2.6$ & $60.9 \pm 21.7$ & $56.5 \pm 17.4$ & $521.8 \pm 87$ & $\begin{array}{c}491.4 \pm \\
39.1\end{array}$ & (Yuyama et al., 2003) \\
\hline Fatty acids con & mposition $n$ & macrocarpa (g & $\left.100 \mathrm{~g}^{-1}\right)$ & & Clement et : & al. (1998) & Yuyama et a & al. (2003) & Osorio et al. (2012) \\
\hline Lauric 12:0 & & & & & - & & - & & $0.014-0.015$ \\
\hline Myristic 14:0 & & & & & $0.42-0$ & & - & & $0.105-0.147$ \\
\hline Palmitic16:0 & & & & & $26.6-4$ & 47.4 & $24.1-4$ & 42.3 & $34.0-39.9$ \\
\hline Palmitoleic 16: & & & & & $5.09-6$ & & $3.9-7$ & & $7.9-10.8$ \\
\hline Stearic $18: 0$ & & & & & $1.84-3$ & & $0.8-3$ & & $1.0-1.6$ \\
\hline Oleic 18:1 & & & & & $37.0-4$ & 49.9 & $42.8-6$ & 60.8 & $38-51.9$ \\
\hline Linoleic $18: 2$ & & & & & $1.19-1$ & & $2.5-5$ & & $2.4-8.6$ \\
\hline Linolenic 18:3 & & & & & $2.10-6$ & & $0.0-1$ & & $0.2-1.5$ \\
\hline & & $\sum$ Saturated fa & tty acids (SFA & & $28.86-5$ & 51.19 & $24.9-4$ & 46.0 & $36.1-41.7$ \\
\hline & & $\Sigma$ Monounsat & urated fatty ac & ids (MFA) & $42.09-5$ & 56.62 & $46.7-6$ & 68.2 & $45.9-62.7$ \\
\hline & & $\Sigma$ Polyunsatur & cated fatty acic & ds (PFA) & $3.39-8$ & & $2.5-6$ & & $6.2-10.1$ \\
\hline & & Ratio PFA/SF & & & $0.12-0$ & & $0.05-0$ & 0.27 & $0.06-0.25$ \\
\hline & & & & Amino acids & Is composition & $(\% g N)$ & & & \\
\hline & & & & & Essential & & & & \\
\hline Phenylalanine & Histidine & Isoleucine & Leucine & Lysine & Methionine & Threonine & Tryptophan & Valine & \\
\hline $2.4 \pm 0.02$ & - & $1.70 \pm 0.05$ & $3.14 \pm 0.03$ & $1.67 \pm 0.06$ & $0.80 \pm 0.01$ & $2.71 \pm 0.08$ & $0.45 \pm 0.02$ & $2.83 \pm 0.09$ & (Yuyama et al., 2003) \\
\hline 6.0 & - & 4.0 & 7.0 & 3.5 & 5.5 & 4.0 & 1.0 & 5.0 & (FAO/WHO, 1973) \\
\hline & & & & & Jon-essential & & & & \\
\hline Aspartic & ic acid & Glutam & hic acid & Alanine & Cysteine & Glycine & Prolamine & Serine & \\
\hline $4.43 \pm 0$ & 0.19 & $4.98 \pm$ & \pm 0.33 & - & $3.51 \pm 0.21$ & $2.87 \pm 0.06$ & $2.57 \pm 0.08$ & $2.72 \pm 0.31$ & (Yuyama et al., 2003) \\
\hline
\end{tabular}

${ }^{*}$ Mean values of three repetitions \pm standard deviation; At least one letter on the line does not represent a significant $95 \%$ difference. Results expressed in dry basis. RDA based on the recommended daily allowances for adult men in the 25-50 age range (NAS/NRC, 1989). - Values not cited by the authors.

biome is predominantly covered by a rain forest, characterized by a hot and humid climate and heavy rains, which are often incident throughout the year (Chisté \& Fernandes, 2016). Due to this particular environment, the Amazon hosts several fruit species that are widely consumed by the local population, found in markets and local nuns (Matos et al., 2019) that are still little explored and represent economic potential to contribute to the food, pharmaceutical and agro industrial fields.

Among the species, the peach palm (pupunha: Brazil; chontaduro, cachipay: Colombia; pejibaye: Costa Rica; chontaruro: 
Equador; pijuayo: Perú; gachipaes: Venezuela) is a palm tree belonging to the Arecaceae family, native representative from Americas, fully domesticated in the Amazon region, with a great variety of races and ecotypes (Bezerra \& Silva, 2016; Bolanho et al., 2014).

The peach palm (Figure 1) is a caespitose palm (multicaule) that can reach up to $20 \mathrm{~m}$ in height. The stem diameter ranges from 15 to $30 \mathrm{~cm}$ and the internodes length from 2 to $30 \mathrm{~cm}$. The internodes are armed with numerous rigid spines from black to dark brown. However, the species commonly used for palm heart production include those that do not cultivate spikes in the peduncle, which facilitates their handling, cultivation and process (Bezerra \& Silva, 2016).

The species commonly used for palm heart production include those which are cultivated without spines on the peduncle and it facilitates the handling, processing and higher yield of the fruits (Morera, 1988; Moro, 1993). The peduncle supports a crown of 15 to 25 pinnate leaves, with the leaflets inserted at different angles. The unopened tender leaves, located in the center of the crown, form the palm heart, an important economic product. The palm heart is removed from the top of the stem corresponding to the central part, with pleasant taste, smooth and low calorie (Bezerra \& Silva, 2016). The monoic inflorescence appears in the armpits of the senescent leaves. After pollination, the bunches may contain between 50 and 1000 single seed fruits, and weigh from 1 to $25 \mathrm{~kg}$. Several factors, such as nutrition or poor pollination, drought, competition, insect attacks and diseases can cause decrease in fruit production and contribute to the low average weight of the bunch. The individual fruits weigh between 10 and $250 \mathrm{~g}$ (3 to $4 \mathrm{~cm}$ in diameter) (Arkcoll \& Aguiar, 1984; Clement \& Mora-Urpí, 1988), with epicarp and mesocarp ranging from yellow to orange (Chisté \& Fernandes, 2016).

The multiple origin of peach palm and the segregation of its hybrids increased the high genetic diversity (Figure 2) (Clement, 1986; Clement \& Mora-Urpí, 1988), therefore, there is visible variability in the fruit shape, color, fibrosis, oil content, starch content, among others. Thus, there are no definite varieties of peach palm, distinguished by "primitive races" or ecotype,
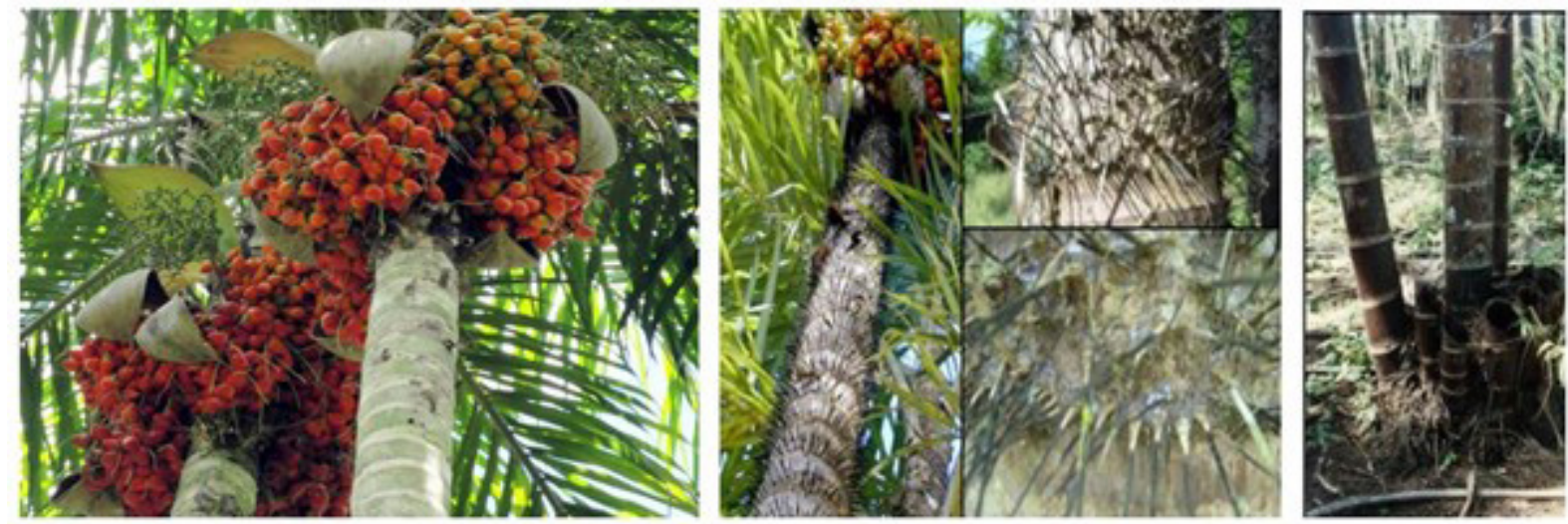

Figure 1. Thorny peach palm tree and smooth peach palm tree (Graefe et al., 2013).

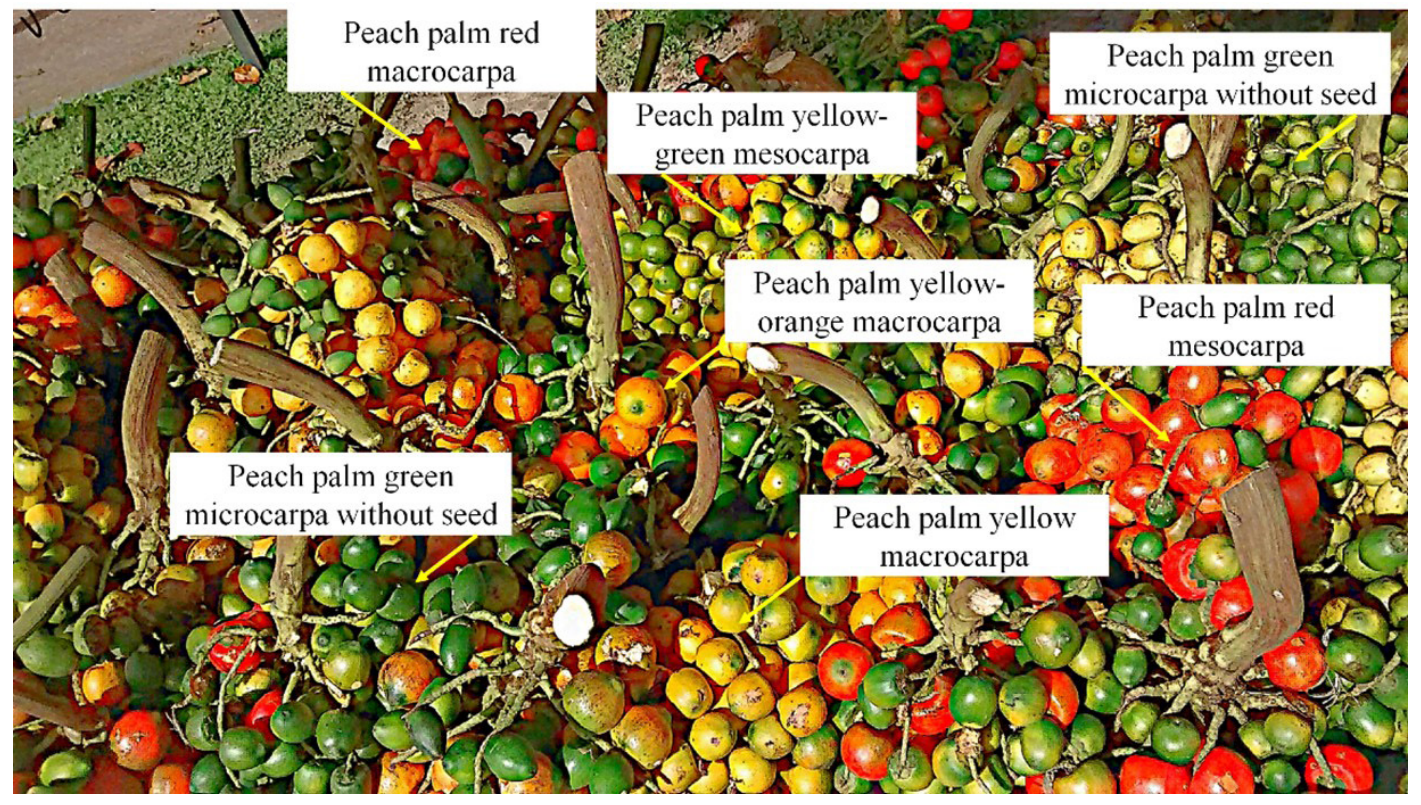

Figure 2. Bunches of peach palm marketed in the metropolitan area of Belém (Pará). 
which are sets of populations of distinct origin, selected and cultivated by a distinct ethnic (Clement \& Mora-Urpí, 1988). In some studies, there are at least three distinct peach palm races, with different colors, flavors, and nutritional constituents (Clement et al., 2004; Costa et al., 2019). The main criterion for classification of fruits is through the thickness of the pulp, separating the peach palm groups in microcarpa, mesocarpa, and macrocarpa. The microcarpa race has small fruits, relatively little pulp compared to seed volume and the pulp is generally fibrous and oily. The mesocarpa and macrocarpa progressively have larger fruits, with a higher pulp percentage in relation to microcarpa, higher starch content and lower lipids (Costa et al., 2019; Mora-Urpí et al., 1997). Studies that correlate physical characterization and chemical composition data show that generally smaller fruits tend to be more fibrous and oily, while larger fruits tend to be rich in starch, with these two major components (starch and lipid) in an inversely proportional ratio (Bezerra \& Silva, 2016; Costa et al., 2019; Leterme et al., 2005). The observed variation demonstrates the importance of determining the chemical composition within each race and/ or population of interest to the consumers or the agroindustry, aiming the quality of the fruits.

\section{Physicochemical composition}

The peach palm fruit presents high levels of dietary fiber, lipids, carotenoids ( $\beta$-carotene, $y$-carotene, lycopene), minerals, essential amino acids (Table 1) and low levels of sodium and sugars (Rosso \& Mercadante, 2007; Espinosa-Pardo et al., 2014; Rojas-Garbanzo et al., 2011). In the Amapá state, through the government program of sustainable development, the peach palm was included in the school menus due to its nutritional composition. The fruits were used in the preparation of porridges or mixed with savory dishes, presented good preference (Brasil, 2015).

In a study by Yuyama et al. (2003), investigating the chemical composition of the mesocarp of three peach palm trees located in Central Amazonia, it was concluded that, in terms of the recommended daily consumption for an adult male in the 25-50 years age group (National Academy of Sciences/National Research Council, 1989), the average contribution of peach palm fruits for mineral elements was low (Table 1). The biological importance of non-essential minerals present in peach palm is unknown, however, traces can be found in animal and plant tissues (Jane et al., 1992).

Due to its nutritional content, the peach palm is considered a fruit of excellent energy value. The absence of gluten and starch richness make this raw material interesting for the development of new products in patients with celiac disease (Bezerra \& Silva, 2016). Nevertheless, it must be assumed that the fruit cannot be consumed fresh due to the presence of anti-nutritional factors (calcium oxalate salts, lectins, some polyphenols, saponins and inhibitors of amylase and trypsin) (Bezerra \& Silva, 2016; RojasGarbanzo et al., 2011). The ingestion of small doses is sufficient to cause intense burning sensation in the mouth and throat, swelling of the airways and suffocation, and if ingested in large doses, it may be fatal. Recovery from poisoning by large doses of calcium oxalate is possible, however the liver and kidneys are permanently affected.
Traditionally, the peach palm fruit is consumed in a unique way in the majority of countries where it is cultivated. After separated from the bunch, the fruits are boiled in salt water at times ranging from 30 to 60 minutes, depending on the variety of the fruit, they are peeled and split lengthwise, then the seeds are extracted and ready for consumption (Chisté \& Fernandes, 2016; Mandel, 1996).

Carrera (1999) studied the chemical and physical properties of isolated starches from six Phenotypes of peach palm, and the starch found represented most of the nutritional composition, suggesting that the fruit is an excellent source of starch in the Amazon region. Jane et al. (1992) studied the isolated starch of peach palm from different parts of Costa Rica and its gelling and thermal properties, the authors found that the concentration of amylose varied from 8 to $19 \%$ and the phosphorus content from 0.049 to $0.054 \%$. Amylopectin branch chain lengths determined by the fraction peak showed degrees of polymerization of 18 and 30 for short and long chain, respectively. The authors attributed variations in physical properties mainly to differences in amylose content and amylopectin structure (Jane et al., 1992).

The peach palm nutritional composition varies depending on the ecotype and geographic region due to the conditions of cultivation, climate and soil of the region, that present great influence on the growth and development of the fruits (Blanco et al., 1990).

Rojas-Garbanzo et al. (2016) in their studies found a significant difference $(\mathrm{p}<0.05)$ in the moisture content of three lots of peach palm harvested in Pérez Zeledón (Costa Rica); however, no variability was found between the Tucurrique (Costa Rica) lots. Among the components analyzed, only the starch content did not present significant differences $(p>0.05)$ between lots from the same area and between regions. This result is extremely important, since the types of products that can be developed from the peach palm fruits are subject to the content of starch (puree, biscuits, bread, cake), therefore, the standardization of the physicochemical characteristics of raw material allows the standardization of the final product quality.

Yuyama et al. (2003) reported peach palm fruits as source of eight essential and non-essential amino acids (Table 1), such as tryptophan and methionine. Although its amino acid content is lower than the minimum daily intake recommended by the Food and Drugs Agency (2018), it is important to consider the peach palm as a source of daily protein requirements for adults and children. It was reported that the protein content of peach palm fruits is not affected by cooking ( $30 \mathrm{~min}$ in boiling water),

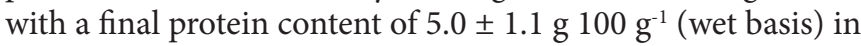
cooked peach palm pulp (Rojas-Garbanzo et al., 2012).

Cysteine was the non-essential amino acid found with the highest amount among flours, being relatively higher in peach palm fruit flours that were not cooked (2.32 to $2.64 \%$ ), for samples without shell and with shell, respectively, and 2.48\% for the flours that have undergone the cooking).

From a nutritional point of view, the protein of the peach palm fruit is of low biological value, a common occurrence in products of plant origin, with methionine and lysine being the most limiting amino acids. 
The most important mineral elements found in the peach palm are potassium, selenium and chromium (Yuyama et al., 2003). Fiber is another component present in peach palm, with a

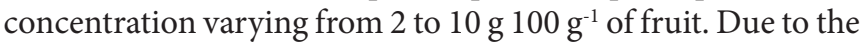
functional properties of the fibers, the interest for the production of products with higher percentage of nondigestible fractions increases, because they are not initially digested by organisms, they are fermented by microorganisms in the intestines, producing compounds (butyrate, ethyl and propionate) that can exert a positive action on the individual's health (Bezerra \& Silva, 2016).

Quesada et al. (2011) reported a low glycemic index of $35 \mathrm{mg} \mathrm{dL}^{-1}$ in pejibaye compared to white bread. Foods with low glycemic index are considered to be beneficial for patients with diabetes and coronary heart disease because the released sugars are absorbed more slowly (Graefe et al., 2013).

Studies involving the proximate composition show carbohydrate values ranging from 50 to $80 \%$, represented mainly in the form of starch (Bezerra \& Silva, 2016; Fernández-Piedra et al., 1995; Quesada et al., 2011).

In addition to direct consumption, peach palm can be used as a raw material for the production of various products, especially in the form of flour (Pires et al., 2019; Valencia et al., 2015), oil (Melhorança \& Pereira, 2012), pasta (Oliveira et al., 2006; Sakurai et al., 2019), edible film (Costa et al., 2019), fermented beverage (Andrade et al., 2003), bacterial substrate for amylase production (Oliveira et al., 2007) and functional food products (Rojas-Garbanzo et al., 2012).

Information on peach palm fruit starch in the literature is still scarce. However, in the study reported by Valencia et al. (2015), the starch content found in peach palm (84.5\%) was compared with the content of cassava starch and starch isolated from a non-conventional source such as the "Cavendish" banana variety. Regarding the structure of the peach palm starch, they are presented in different forms, such as spherical and oval, with predominance of truncated form on one side, as this form is observed in tapioca starch granules and modified tapioca starch (Liu, 2005; Makmoon et al., 2013; Valencia et al., 2015).

The high amylose content found in peach palm starch (19.3\%) indicates that this type of starch can be used as raw material for the preparation of films and coatings to be used in food products (Valencia et al., 2015).

A previous study reported that the peach palm oil contains omega-3 (linolenic acid), omega-6 (linoleic), and omega-9 (oleic acid) fatty acids, commonly associated with decreasing in Low Density Lipoprotein (LDL) levels and risk of cardiovascular diseases (Bezerra \& Silva, 2016). However, the fruits present high variability between the bunches and the harvest season (Arkcoll \& Aguiar, 1984; Graefe et al., 2013). Carvalho et al. (2013b) reported that Wistar rats supplemented with red peach palm before and after lactation showed increasing in High Density Lipoprotein (HDL)-cholesterol, as well as reduction of body weight, total cholesterol and triglycerides. In this sense, peach palm pulp oil can be considered a good option for human consumption (Clement et al., 1998; Osorio et al., 2012).
Regarding to the saturated fatty acids (Table 1), palmitic acid was the one with the highest concentrations in the peach palm pulp, but in the seed, the predominant fatty acids are the lauric and myristic ones. According to Carvalho et al. (2013a), the moisture content, lipids and carotenoids are the components that best represent the genetic diversity of the peach palm. The B02-P30 matrix had the highest lipid content, with values between 8.25 and $40.83 \%$. Ferreira and Pena (2003), in a study on the hygroscopic behavior of the peach palm flour, observed a lipid content ranging from $6.1 \%$ to $9.8 \%$. However, Oliveira et al. (2006) and Carvalho et al. (2009) reported values of $11.56 \%$ and $10.3 \%$ lipids, respectively, in peach palm flour studies.

Due to the high concentration of oleic fatty acid the peach palm oil has a high nutritional value, liquid at room temperature and less suspect to oxidation compared to oils with a higher proportion of linoleic acid (Santos et al., 2017).

Another property that can be observed for peach palm is the antimicrobial activity of the oil extracted from the bark of two species (Table 2). Significant levels of carotenoids are found in peach palm (Bereau et al., 2003). Vitamin A deficiency is a serious public health problem and mainly affects children, causing clinical manifestations known as night blindness (Bereau et al., 2003). Peach palm is considered a good strategy to prevent or remedy vitamin A deficiencies. Since, once added in the diet, it increases the hepatic content (Bezerra \& Silva, 2016; Yuyama et al., 1991; Yuyama \& Cozzolino, 1996).

In order to deepen researches on genetic improvement of peach palm tree species, cultivated in the Northern Brazil, the peach palm pulp total carotenoid content ranged from 0.8 to

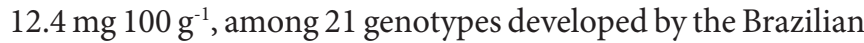
Agricultural Research Corporation, and demonstrated wide variation among fruits of the same species, grown in the same region (Carvalho et al., 2013b).

Furtado et al. (2004) studied the concentration of carotene, trans- $\beta$-carotene, cis- $\beta$-carotene, and carotenoids in vegetables and fruits commercialized in Costa Rica, reporting values for peach palm of 4.2, 59.1, 93.2, 20.5 and $63.7 \mu \mathrm{g} \mathrm{g}^{-1}$ for $\alpha$-carotene, trans- $\beta$-carotene, cis- $\beta$-carotene, trans-lycopene and cis-lycopene, respectively.

Blanco \& Muñoz (1992) found similar carotenoid contents in fresh and cooked peach palm, and determined that the retention of nutrients after cooking is greater than $85 \%$. Rosso \& Mercadante (2007) quantified carotenoids in six Amazonian fruit species and found that peach palm is a good source of provitamin A, with a total carotenoid content of $19.80 \mathrm{mg}$ $100 \mathrm{~g}^{-1}$. Rojas-Garbanzo et al. (2011) identified nine carotenoids in fresh peach palm from Costa Rica, the most predominant as the $\beta$-carotene.

Costa et al. (2019) found values of total carotenoids of 57.0, 95.6 and $79.8 \mu \mathrm{g} \mathrm{g}^{-1}$, for micro, meso and macrocarpa peach palm ecotypes, respectively.

In a study performed by Matos et al. (2019), it was verified a high peach palm peel potential for carotenoid prospecting as a strategy for valorization of the product with no current commercial value. The content of carotenoids in the peel was ten times higher 


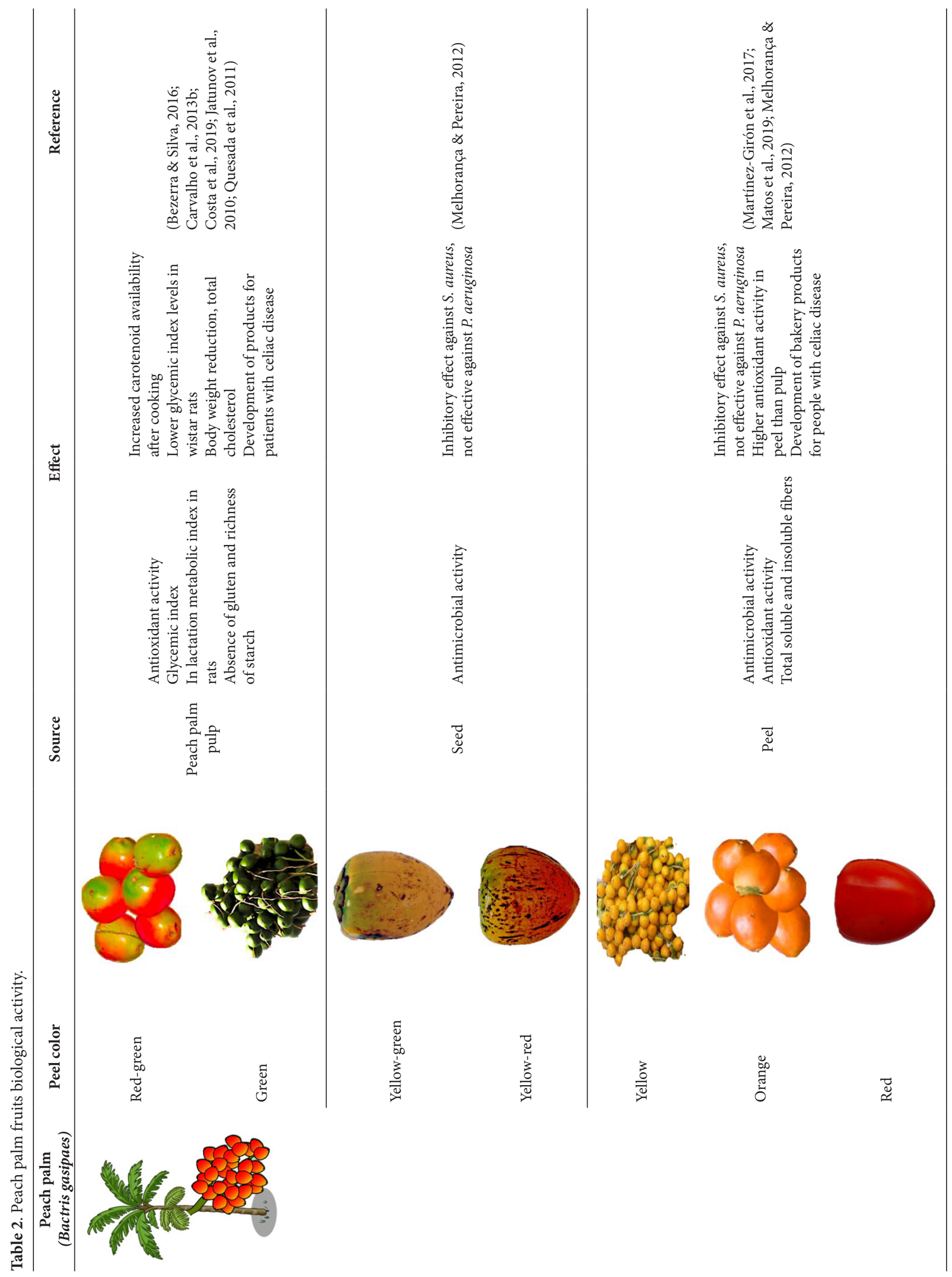




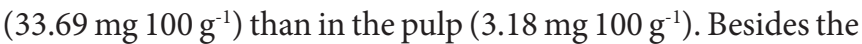
pro-vitamin A activity of some carotenoids, the consumption of foods rich in this compound is associated with increased immune response and reduced risk of degenerative diseases such as cancer, macular degeneration, cataracts and cardiovascular diseases (Table 2). Carotenoids can also undergo changes due to degradation during the process of prolonged cooking of the food and its storage through the action of enzymes, light and oxygen. Thus, vegetable and fruit dehydration can reduce the biological activity of carotenoids (Sentanin \& Amaya, 2007).

In the study performed by Rojas-Garbanzo et al. (2012), the authors reported that the content of total carotenoids was influenced by the cooking and drying of peach palm, where the samples presented an increase of $17 \%$ in carotenoids in the fresh peach palm. The cooking process softens both cell walls and macromolecules, such as fatty acids and proteins that encapsulate carotenoids, making them more available.

The peach palm gas chromatography analysis revealed the existence of several $\delta$-5-sterols, cholesterol, campesterol, stigmasterol, $\beta$-sitosterol and $\delta$-5-avenasterol). A High Performance Liquid Chromatography (HPLC) study of tocopherols and tocotrienols showed that $\alpha$-tocopherol predominates in the bands standards (Lubrano \& Robin, 1997). Bereau et al. (2003) reported low levels of vitamin $\mathrm{E}$ in peach palm samples; however, the results of antioxidant activity were more similar to the olive oil than palm oil. Tocopherols have a chemical structure similar to cholesterol, with a bactericidal, fungicidal and anti-inflammatory action. Studies have shown that these compounds play an important role in reducing blood cholesterol by blocking its absorption (Tango et al., 2004; Ye et al., 2010).

\section{Marketing and consumption}

Products made from the peach palm or peach palm tree as palm heart (Table 3), are considered great economic potentials for the national and international markets (Godoy et al., 2007; Graefe et al., 2013).

Some evidence suggests that red and lower lipid content peach palm are preferred for the production of canned fruits and jellies (Graefe et al., 2013). Since damaged or deformed fruits can be used in the elaboration of flour (Godoy et al., 2007).

Table 3. Main products made from peach palm found in the literature.

\begin{tabular}{|c|c|c|}
\hline Peach palm variety & Product & Reference \\
\hline $\begin{array}{l}\text { Micro, meso and } \\
\text { macrocarpa }\end{array}$ & Edible films & (Costa et al., 2019) \\
\hline Mesocarpa & Fermented drink & (Mora-Urpí et al., 1997) \\
\hline & Pickled & (Pelais et al., 2017) \\
\hline Microcarpa & Oil & $\begin{array}{c}\text { (Arkcoll \& Aguiar, 1984; } \\
\text { Ordoñez-Santos et al., 2019) }\end{array}$ \\
\hline $\begin{array}{l}\text { Micro, meso and } \\
\text { macrocarpa }\end{array}$ & $\begin{array}{l}\text { Peach palm flour } \\
\text { and starch }\end{array}$ & (Pires et al., 2019) \\
\hline- & Cake mix & (Martínez-Girón et al., 2017) \\
\hline- & Snacks & (Carvalho et al., 2009) \\
\hline Microcarpa & Pasta & $\begin{array}{l}\text { (Oliveira et al., 2006; } \\
\text { Sakurai et al., 2019) }\end{array}$ \\
\hline
\end{tabular}

In Cali (Colombia), peach palm has reached a visible presence in large supermarkets and malls, where fruits are sold fresh and more limited quantities of processed fruits are available on the shelves. The processed fruits are vacuum packed or canned in brine or processed into marmalade. In the city of Popaya'n (Colombia), the peach palm chips are sold in small packages. Despite just entering in major markets, it is believed that the chips have great potential (Graefe et al., 2013).

In Brazil, more specifically in the Amazon, the peach palm fruits are marketed in nuns or supermarkets, and fruits with oily characteristics are the most sought by the population (Bezerra \& Silva, 2016). In order to know if the fruit has this characteristic, consumers traditionally grind a piece of raw peach palm between the fingers and rub it to identify the oily aspect (Godoy et al., 2007).

In a study performed for the preparation of canned peach palm, the sensorial analysis presented excellent results demonstrating that there were no significant differences between the flavor of the canned fruit and the cooked one (Pelais et al., 2017).

Tracy (1987) determined that $10 \%$ peach flour could serve as a substitute for wheat flour in the baking industry, producing an excellent baking quality.

The peach palm was also studied for possible use in mass production from a mixture of $15 \%$ peach palm flour and $85 \%$ wheat flour. In the cooking tests of spaghetti and spiked pasta, the addition of peach palm flour to the dough did not significantly change its quality and texture (Oliveira et al., 2006).

However, in a later study, the addition of cassava starch, peach palm flour and gilded linseed allowed the production of well-structured dry pasta. In addition, the mass had a good rate of acceptance and intention of purchase by the tasters (Sakurai et al., 2019).

Rosa et al. (2016) developed a pre-mix for cake with peach palm (Bactris gasipaes Kunth) flour, free of gluten. It is important that the market offers bakery products containing the same sensory and nutritional quality as products that present gluten to people with celiac disease (Tracy, 1987).

Martínez-Girón et al. (2017) developed cakes with different proportions of peach palm flour, and the authors found in their studies that the peel flour can be considered as a natural food coloring alternative for cooked products, in order to replace artificial food coloring, besides increasing the biological properties of cakes.

The indigenous peoples of the Amazon use peach palm fruits to produce caiçuma or cachiri, a fermented alcoholic beverage similar to beer (Andrade et al., 2003; Graefe et al., 2013).

The peach palm in the form of flour is an alternative to avoid saturation of the fresh fruit market and to diversify its demand (Bezerra \& Silva, 2016). Peach palm flour was used in the production of extruded maize products and may be considered an interesting ingredient to improve the carotenoid content, since the extrusion process did not decrease the carotenoid content in the product (Basto et al., 2016). 
Rojas-Garbanzo et al. (2011) studying the identification and quantification of carotenoids in peach palm flour concluded that more research is needed to control the effects that processing and storage have on carotenoids and their bioavailability.

In a later study, Rojas-Garbanzo et al. (2012) found that peach palm flour can also be used as an ingredient rich in bioactive compounds for the formulation of functional foods.

The peach palm flour was also used for the elaboration of ice cream cone and they presented high content of carotenoids in comparison to the traditional cones. In addition, the peach palm flour showed similar texture to the cones made with wheat flour (Sakurai et al., 2019). It is noteworthy that the peach palm ice cream cone does not contain gluten, providing consumption by new markets, such as the celiac disease one (Santos et al., 2017). Therefore, the possibility of developing gluten-free products such as peach palm flour may increase the supply of food products to individuals with celiac disease and contribute to a more diversified diet for this population group.

For the first time, the potential use of the peach palm peel, which is considered agro industrial residue in Brazil, was investigated for the quantification and identification of carotenoids and it can be concluded that the peach palm peel has a high potential to be used as a source of carotenoids by food, cosmetic and pharmaceutical industries as bioactive colorants and/or ingredients (Matos et al., 2019).

A dehydrated product with film characteristics based on peach palm and tucupi was studied by Costa et al. (2019) and they obtained a product with superior technological quality, considered as a good source of energy value and carotene. And depending on the characteristic of the variety used, the product can be applied as a separator of components, as in pizzas, which the dough has low moisture and the filling has high moisture, to replace the algae in sushi, as protection of foods with high activity of water or to prevent the exudation of fresh or frozen products.

\section{Conclusion}

The peach palm fruit, fresh, cooked or dried, may be considered as a source of bioactive compounds with significant antioxidant capacity, and its carotenoid content is higher than that found for other tropical fruits such as banana, mango, melon and papaya. Despite its low protein content, peach palm contains all essential amino acids, with methionine and lysine present at levels below those recommended. Peach palm provides few essential minerals, with an emphasis on potassium, selenium and chromium, which are present in amounts corresponding to 12,9 and $9 \%$ of the recommended daily rates, respectively. Flour is the main form of processing and conservation of peach palm fruit and can be used as an ingredient for the formulation of functional foods, considered an excellent source of carbohydrates (59\%) and energy (417 kcal $100 \mathrm{~g}^{-1}$ ). The addition of the peach palm peel increases the content of carotenoids, fatty acids and dietary fibers. This review suggests that the processing and marketing of peach palm have a significant potential to increase food security and fruit yields. To perform these potential gains, participatory research is needed that directly engages stakeholders and addresses multiple challenges in the different stages of industrialization and marketing.

\section{Conflict of interest}

The authors declare no financial interests or personal relationships to influence the present study.

\section{Acknowledgements}

The authors would like to thank PROPESP/UFPA (Provost's Office for Research and Graduate Studies of the Federal University of Pará), CNPq (National Research and Development Council, processes 308021/2015-0 and 477013/2013-282 9), and CAPES (Coordination for the Improvement of Higher Education Personnel) for funding the study (Financial Code 001).

\section{References}

Andrade, J. S., Pantoja, L., \& Maeda, R. N. (2003). Improvement on beverage volume yield and on process of alcoholic beverage production from pejibaye (Bactris gasipaes Kunth). Food Science and Technology, 23, 34-38.

Arkcoll, D., \& Aguiar, J. P. (1984). Peach palm (Bactris gasipaes H.B.K.), a new source of vegetable oil from the wet tropics. Journal of the Science of Food and Agriculture, 35(5), 520-526. http://dx.doi. org/10.1002/jsfa.2740350508.

Basto, G. J., Carvalho, W. P., Soares, A. G., Costa, H. T. G. B., Chávez, D. W. H., Godoy, R. L. O., \& Pacheco, S. (2016). Physicochemical properties and carotenoid content of extruded and non-extruded corn and peach palm (Bactris gasipaes, Kunth). LebensmittelWissenschaft + Technologie, 69, 312-318. http://dx.doi.org/10.1016/j. lwt.2015.12.065.

Bereau, D., Benjelloun-Mlayah, B., Banoub, J., \& Bravo, R. (2003). FA and unsaponifiable composition of five Amazonian palm kernel oils. Journal of the American Oil Chemists' Society, 80(1), 49-53. http:// dx.doi.org/10.1007/s11746-003-0649-5.

Bezerra, C. V., \& Silva, L. H. M. (2016). Pupunha (Bactris gasipaes): general and consumption aspects. In K. Kristbergsson \& J. Oliveira (Eds.), Traditional foods (pp. 399-405). New York: Springer.

Blanco, A., \& Muñoz, L. (1992). Content and bioavailability of carotenoids from peach palm fruit (Bactris gasipaes) as a source of vitamin A. Archivos Latinoamericanos de Nutricion, 42, 146-154. PMid:1341854.

Blanco, A., Lowery, M., Montero, M., Mora-Urpí, J., \& Rojas, M. (1990). El pejibaye: su uso en la alimentación humana. San José: Instituto Costarricense de Investigación y Enseñanza en Nutrición y Salud.

Bolanho, B., Danesi, E., \& Beléia, A. (2014). Characterization of flours made from peach palm (Bactris gasipaes Kunth) by-products as a new food ingredient. Journal of Food and Nutrition Research, 53, 51-59.

Brasil, Ministério da Saúde. (2015). Alimentos regionais brasileiros (2. ed.). Brasília: Ministério da Saúde.

Carrera, L. (1999). Isolation and characterisation of pejibaye starch. Journal of Applied Botany and Food Quality, 73, 122-127.

Carvalho, A. V., Vasconcelos, M. A. M., Silva, P. A., \& Ascheri, J. L. R. (2009). Production of third generation snacks by extrusion-cooking of pupunha and cassava flour mixtures. Brazilian Journal of Food Technology, 12, 277-284.

Carvalho, A., Beckman, J., Maciel, R., \& Farias, T. No. (2013a). Características físicas e químicas de frutos de pupunheira no Estado 
do Pará. Revista Brasileira de Fruticultura, 15, 763-768. http://dx.doi. org/10.1590/S0100-29452013000300013.

Carvalho, R. P., Lemos, J. R. G., Sales, R. A. A., Martins, M. G., Nascimento, C. H., Bayona, M., Marcon, J. L., \& Monteiro, J. B. (2013b). The consumption of red pupunha (Bactris gasipaes Kunth) increases HDL cholesterol and reduces weight gain of lactating and post-lactating Wistar. The Journal of Aging Research \& Clinical Practice, 2(3), 257-260. PMid:25580386.

Chisté, R., \& Fernandes, E. (2016). Bioactive compounds from Amazonian fruits and their antioxidant properties. In L. R. Silva \& B. M. Silva (Eds.), Natural bioactive compounds from fruits and vegetables as health promoters: part I (p. 244-264). Sharjah: Bentham Science. http://dx.doi.org/10.2174/9781681082394116010011.

Clement, C. (1986). The pejibaye palm (Bactris gasipaes H.B.K.) as an agroforestry component. Agroforestry Systems, 4(3), 205-219. http:// dx.doi.org/10.1007/BF02028355.

Clement, C., \& Mora-Urpí, J. (1988). Phenotypic variation of peach palm observed in the Amazon basin. In C. R. Clement \& L. Coradin (Eds.), Final report (revised): Peach palm (Bactris gasipaes H.B.K.) germplasm bank - U.S. Agency for International Development (grant number DAN-5542-G-SS-2093). Manaus: Instituto Nacional de Pesquisas da Amazônia, Centro Nacional de Manaus.

Clement, C., Aguiar, J. P., \& Arkcoll, D. (1998). Composição química do mesocarpo e do óleo de três populações de pupunha (Bactris gasipaes) do Rio Solimões, Amazonas, Brasil. Revista Brasileira de Fruticultura, 20, 115-118.

Clement, J., Weber, C., Van Leeuwen, D., Domian, C. A., Cole, D. M., Lopez, L. A. A. \& Agüello, H. (2004). Why extensive research and development did nor promote use of peach palm fruit in Latin America. Agroforestry Systems, 61(1-3), 195-206. http://dx.doi. org/10.1023/B:AGFO.0000028999.84655.17.

Costa, R. D. S., Rodrigues, A. M. C., Laurindo, J. B., \& Silva, L. H. M. (2019). Development of dehydrated products from peach palm - tucupi blends with edible film characteristics using refractance window. Journal of Food Science and Technology, 56(2), 560-570. http://dx.doi.org/10.1007/s13197-018-3454-x. PMid:30906013.

Espinosa-Pardo, F. A., Martinez, J., and Martinez-Correa, H. A. (2014). Extraction of bioactive compounds from peach palm pulp (Bactris gasipaes) using supercritical CO2. J. Supercrit. Fluids, 93, 2-6. https:// doi.org/10.1016/j.supflu.2014.05.010.

Food and Agriculture Organization - FAO/WHO. (1973). Report of a Joint Committee: Energy and protein requirements. Technical Report Series. Rome: World Health Organization.

Fernández-Piedra, M., Blanco-Metzler, A., \& Mora-Urpí, J. (1995). Contenido de ácidos grasos en cuatro poblaciones de pejibaye, Bactris gasipaes (Palmae). Revista de Biología Tropical, 43(1-3), 61-66. PMid:8728758.

Ferreira, C. D., \& Pena, R. S. (2003). Hygroscopic behavior of the pupunha flour (Bactris gasipaes). Food Science and Technology, 23(2), 251-255. http://dx.doi.org/10.1590/S0101-20612003000200025.

Food and Drugs Agency - FDA. (2018). Nutrition labeling of food. Retrieved from https:/www.accessdata.fda.gov/scripts/cdrh/cfdocs/ cfcfr/CFRSearch.cfm? fr $=101.9$

Furtado, J., Siles, X., \& Campos, H. (2004). Carotenoid concentrations in vegetables and fruits common to the Costa Rican diet. International Journal of Food Sciences and Nutrition, 55(2), 101-113. http://dx.doi. org/10.1080/09637480410001666522. PMid:14985182.

Godoy, S., Pencue, L., Ruiz, A., \& Montilla, D. (2007). Clasificación automática de chontaduro (Bactris gasipaes) para su aplicación en conserva, mermelada y harinas. Facultd de Ciencias Agropecuarias, $5,137-146$.

Graefe, S., Dufour, D., Van Zonneveld, M., Rodriguez, F., \& Gonzalez, A. (2013). Implications for biodiversity conservation, natural. Biodiversity and Conservation, 22(2), 269-300. http://dx.doi. org/10.1007/s10531-012-0402-3.

Jane, J., Shen, L., Chen, J., Lim, S., Kasemsuwan, T., \& Nip, W. K. (1992). Physical and chemical studies of taro starches and flours. Cereal Chemistry, 69, 528-535.

Jatunov, S., Quesada, S., Díaz, C., \& Murillo, E. (2010). Carotenoid composition and antioxidant activity of the raw and boiled fruit mesocarp of six varieties of Bactris gasipaes. Archivos Latinoamericanos de Nutricion, 60(1), 99-104. PMid:21090177.

Leterme, P., García, M., Londõno, A., Rojas, M., Buldgen, A., \& Souffrant, W. (2005). Chemical composition and nutritive value of peach palm (Bactris gasipaes Kunth) in rats. Journal of the Science of Food and Agriculture, 85(9), 1505-1512. http://dx.doi.org/10.1002/jsfa.2146.

Liu, Q. (2005). Understanding starches and their role in foods. In S. Cui (Ed.), Food carbohydrates: chemistry, physical properties, and applications (pp. 309-355). Boca Raton: Taylor \& Francis.

Lubrano, C., \& Robin, J. (1997). Étude des composés majeurs d'huiles de pulpe de fruits de six espèces de palmiers de Guyane. Acta Botanica Gallica, 144, 495-499. http://dx.doi.org/10.1080/125380 78.1997.10515792.

Makmoon, T., Foungfuchat, A., \& Jiratumnukul, N. (2013). Modified tapioca starch as a rheology modifier in acrylic dispersion system. Progress in Organic Coatings, 76(6), 959-962. http://dx.doi.org/10.1016/j. porgcoat.2012.10.021.

Mandel, N. (1996). Mechanism of stone formation. Seminars in Nephrology, 16(5), 364-374. PMid:8890393.

Martínez-Girón, J., Figueroa-Molano, A., \& Ordóñez-Santos, L. (2017). Effect of the addition of peach palm (Bactris gasipaes) peel flour on the color and sensory properties of cakes. Food Science and Technology (Campinas), 37(3), 418-424. http://dx.doi.org/10.1590/1678-457x.14916.

Matos, K. A. N., Barbosa, A. P. P., Lima, D. P., Mercadante, A. Z., \& Chisté, R. C. (2019). Peels of tucumã (Astrocaryum vulgare) and peach palm (Bactris gasipaes) are by-products classified as very high carotenoid sources. Food Chemistry, 272, 216-221. http://dx.doi. org/10.1016/j.foodchem.2018.08.053. PMid:30309535.

Melhorança, A. L. Fo., \& Pereira, M. R. R. (2012). Atividade antimicrobiana de óleos extraídos de açaí e de pupunha sobre o desenvolvimento de Pseudomonas aeruginosa e Staphylococcus aureus. Bioscience Journal, 28, 598-604.

Mora-Urpí, J., Weber, J., \& Clement, C. (1997). Peach palm, Bactris gasipaes Kunth. Rome: IPGRI.

Morera, J. (1988). Caracterizacion de los estipetes de pejibaye (Bactris gasipaes) en base a las espinas. Agronomia Costarricense, 13, 111-114.

Moro, J. (1993). A breeding program for Bactris gasipaes (Pejibaye Palm). Acta Horticulturae, (360), 135-139. http://dx.doi.org/10.17660/ ActaHortic.1994.360.17.

National Academy of Sciences/National Research Council - NAS/NRC. (1989). Recommended dietary allowances (10th ed.). Washington: National Academy Press.

Neri-Numa, I. A., Sancho, R. A. S., Pereira, P. A., \& Pastore, G. M. (2018). Small Brazilian wild fruits: nutrients, bioactive compounds, health-promotion properties and commercial interest. Food Research International, 103, 345-360. http://dx.doi.org/10.1016/j. foodres.2017.10.053. PMid:29389624.

Oliveira, A. N., Oliveira, L. A., Andrade, J. S., \& Chagas, A. F. Jr. (2007). Produção de amilase por rizóbios, usando farinha de pupunha como 
substrato. Food Science and Technology, 27, 61-66. http://dx.doi. org/10.1590/S0101-20612007000100011.

Oliveira, M. K., Martinez-Flores, H., Andrade, J., Garnica-Romo, M., \& Chang, Y. (2006). Original article use of pejibaye flour (Bactris gasipaes Kunth) in the production of food pastas. International Journal of Food Science \& Technology, 41(8), 933-937. http://dx.doi. org/10.1111/j.1365-2621.2005.01145.x.

Ordoñez-Santos, L. E., Martínez-Girón, J., and Rodríguez-Rodríguez, D. X. (2019). Extraction of total carotenoids from peach palm fruit (Bactris gasipaes) peel by means of ultrasound application and vegetable oil. Dyna, 86, 98-103.

Osorio, J. R., Vinasco, L. E., \& Estupiñán, J. A. (2012). Estudio Comparativo del contenido de ácidos grasos en 4 variedades de chontaduro (Bactris gasipaes) de la refión del Pacífico Colombiano. Revista de Ciencias, 16, 123-129. http://dx.doi.org/10.25100/rc.v16i0.508.

Pelais, A. C., Pinheiro, B. P., \& Santos, I. N. S. (2017). Processo de elaboração da pupunha (Bactris gasipaes Kunt) em conserva. BR1020170266311.

Pérez-Mateos, M., Bravo, L., Goya, L., Gómez-Guillén, C., \& Montero, P. (2005). Quercetin properties as a functional ingredient in omega3 -enriched fish gels fed to rats. Journal of the Science of Food and Agriculture, 85(10), 1651-1659. http://dx.doi.org/10.1002/jsfa.2164.

Pires, M. B., Amante, E. R., Lopes, A. S., Rodrigues, A. M. C., \& Silva, L. H. M. (2019). Peach palm flour (Bactris gasipae KUNTH): potential application in the food industry. Food Science and Technology (Campinas), 39(3), 613-619. http://dx.doi.org/10.1590/fst.34617.

Quesada, S., Azofeifa, G., Jatunov, S., Jiménez, G., \& Gó, G. (2011). Carotenoids composition, antioxidant activity and glycemic index of two varieties of Bactris gasipaes. Emirates Journal of Food and Agriculture, 23, 482-489.

Rojas-Garbanzo, C., Pérez, A. M., Bustos-Carmona, J., \& Vaillant, F. (2011). Identification and quantification of carotenoids by HPLCDAD during the process of peach palm (Bactris gasipaes H.B.K.) flour. Food Research International, 44(7), 2377-2384. http://dx.doi. org/10.1016/j.foodres.2011.02.045.

Rojas-Garbanzo, C., Pérez, A. M., Pineda Castro, M., \& Vaillant, F. (2012). Major physicochemical and antioxidant changes during peach-palm (Bactris gasipaes H.B.K.) flour processing. Fruits, 67(6), 415-427. http://dx.doi.org/10.1051/fruits/2012035.

Rojas-Garbanzo, C., Pérez, A. M., Vaillant, F., \& Pineda-Castro, M. (2016). Physicochemical and antioxidant composition of fresh peach palm (Bactris gasipaes Kunth) fruits in Costa Rica. Brazilian Journal of Food Technology, 19(0), e2015097. http://dx.doi.org/10.1590/19816723.9715

Rosa, A. M. B., Negrão, B., Ribeiro, S. C., \& Mattieto, R. (2016, October 24-27). Pré-mix para bolo com farinha de pupunha. In XXV Congresso Brasileiro de Ciência e Tecnologia de Alimentos (pp. 1-6). Rio Grande do Sul: FAURGS
Rosso, V. V., \& Mercadante, A. (2007). Identification and quantification of carotenoids, by HPLC-PDA-MS/MS, from Amazonian fruits. Journal of Agricultural and Food Chemistry, 55(13), 5062-5072. http://dx.doi.org/10.1021/jf0705421. PMid:17530774.

Sakurai, Y. C., Rodrigues, A. M. C., Pires, M., \& Silva, L. H. M. (2019). Quality of pasta made of cassava, peach palm and golden linseed flours. Food Science and Technology (Campinas), 2061, 1-7.

Santos, M. F., Alves, R., Brito, E., Silva, S., \& Silveira, R. M. (2017). Scientific communication quality characteristis of fruits and oils of palms native to the Brazilian Amazon. Revista Brasileira de Fruticultura, 39(spe), e-305. http://dx.doi.org/10.1590/0100-29452017305.

Sentanin, M., \& Amaya, D. B. R. (2007). Teores de carotenóides em mamão e pêssego determinados por cromatografia líquida de alta eficiência. Food Science and Technology, 27(1), 13-19. http://dx.doi. org/10.1590/S0101-20612007000100003.

Serrano, M., Umaña, G., \& Sáenz, M. (2011). Fisiología poscosecha, composición química y capacidad antioxidante de frutas de pejibaye (Bactris gasipaes Kunth) cv. tuira dari én cosechadas a tres diferentes edades. Agronomia Costarricense, 35(2), 3575-3587.

Tango, J., Carvalho, C. R., \& Soares, N. (2004). Caracterização física e química de frutos de abacate visando a seu potencial para extração de óleo. Revista Brasileira de Fruticultura, 26(1), 17-23. http://dx.doi. org/10.1590/S0100-29452004000100007.

Tracy, M. (1987). Utilización de harina de pejibaye (Bactris gasipaes H.B.K.) en la elaboración de pan. Archivos Latinoamericanos de Nutricion, 37, 122-131. PMid:3454612.

Valencia, G. A., Moraes, I. C. F., Lourenço, R. V., Bittante, A. M. Q. B., \& Sobral, P. J. D. A. (2015). Physicochemical, morphological, and functional properties of flour and starch from peach palm (Bactris gasipaes k.) fruit. Starch, 67(1-2), 163-173. http://dx.doi.org/10.1002/ star.201400097.

Ye, J., Chang, W., Hsieh, D. J., \& Hsiao, M. (2010). Extraction and analysis of $\beta$-Sitosterol in herbal medicines. Journal of Medicinal Plants Research, 47, 522-527.

Yuyama, L. K., \& Cozzolino, S. M. (1996). Efeito da suplementação com pupunha como fonte de vitamina A em dieta: estudo em ratos. Revista de Saude Publica, 30, 61-66. http://dx.doi.org/10.1590/ S0034-89101996000100008. PMid:9008923.

Yuyama, L. K., Aguiar, J. P., Yuyama, K., Clement, C. R., Macedo, S. H., Fávaro, D. I., Afonso, C., Vasconcellos, M. B., Pimentel, S. A., Badolato, E. S., \& Vannucchi, H. (2003). Chemical composition of the fruit mesocarp of three peach palm (Bactris gasipaes) populations grown in Central Amazonia, Brazil. International Journal of Food Sciences and Nutrition, 54(1), 49-56. PMid:12701237.

Yuyama, L. K., Aguiar, J. P., Yuyama, K., Macedo, S. H., Fávaro, D. I., Afonso, C., \& Vasconcellos, M. B. (1991). Determinação de elementos essenciais e não essenciais de pupunheira. Horticultura Brasileira, 17(2), 91-95. http://dx.doi.org/10.1590/S0102-05361999000200003. 